\title{
Distal Bile Duct Cancer Pathologic Primary Tumor TNM Finding v8
}

National Cancer Institute

\section{Source}

National Cancer Institute. Distal Bile Duct Cancer Pathologic Primary Tumor TNM

Finding v8. NCI Thesaurus. Code C134797.

A pathologic finding about one or more characteristics of distal bile duct cancer, following the rules of the TNM AJCC V8 classification system as they pertain to stag ing of the primary tumor. 